\title{
Influence of the flood pulse on the reproduction of Tocantinsia piresi (Miranda Ribeiro) and Auchenipterus nuchalis (Spix \& Agassiz) (Auchenipteridae) of the middle Xingu River, Brazil
}

\author{
Freitas, TMS. ${ }^{*}$, Prudente, BS. ${ }^{b}$, Oliveira, VA. ${ }^{b}$, Oliveira, MNC. ${ }^{a}$, Prata, EG. ${ }^{a}$, \\ Leão, $H^{b}$ and Montag, LFA. ${ }^{b}$ \\ ${ }^{a}$ Faculdade de Ciências Naturais, Universidade Federal do Pará - UFPA, Campus Universitário do Marajó, \\ Conjunto Bandeirante, Aeroporto, CEP 68800-000, Breves, PA, Brazil \\ 'Laboratório de Ecologia e Conservação, Instituto de Ciências Biológicas, Universidade Federal do Pará - UFPA, \\ Rua Augusto Corrêa, 01, Guamá, CP 479, CEP 66075-110, Belém, PA, Brazil \\ *e-mail: freitastms@gmail.com
}

Received: April 23, 2014 - Accepted: November 4, 2014 - Distributed: August 31, 2015

(With 4 figures)

\begin{abstract}
This study investigates the influence of the flood pulse on the reproductive biology of the auchenipterids Tocantisia piresi (Miranda Ribeiro, 1920) and Auchenipterus nuchalis (Spix \& Agassiz, 1829) from the middle Xingu River in the Brazilian state of Pará. The specimens were collected every three months between April, 2012, and January, 2014, covering four distinct periods (flood, ebb, dry, and filling). The sex ratio, size at first maturity, gonadosomatic index, and condition factor were analysed in the two species, and evaluated in the context of the different hydrological periods. A total of 897 specimens of T. piresi were collected, of which 467 were female, and 430 males, and 383 A. nuchalis (286 females and 97 males). In T. piresi, the sex ratio was biased only in the filling and ebb periods, whereas in A. nuchalis, it departed significantly from the expected ratio of 1:1 in all periods, with a predominance of females. The female $T$. piresi mature at a smaller size than the males, with the opposite of the pattern being recorded in $A$. nuchalis. In T. piresi, the breeding peak was observed during the low water periods, whereas in A. nuchalis, the peak was recorded in the flood periods. Male and female $T$. piresi presented similar positively allometric growth rates, whereas in A. nuchalis, growth was negatively allometric, but rates were different between genders. A higher condition factor was recorded in the females of both species during the ebb period. Overall, the results of this study reveals distinct flood pulse effects on the reproductive parameters of the two auchenipterid species studied; for $A$. nuchalis the spawning seems to happen at the flood period and for $T$. piresi at the dry season of the middle Xingu River.
\end{abstract}

Keywords: Amazon, Auchenipteridae, flood pulse, fish reproduction.

\section{Influência do pulso de inundação na reprodução de Tocantinsia piresi (Miranda Ribeiro) e Auchenipterus nuchalis (Spix \& Agassiz) (Auchenipteridae) do médio Rio Xingu, Brasil}

\section{Resumo}

Analisamos a influência do pulso de inundação na biologia reprodutiva dos auchenipterídeos Tocantisia piresi (Miranda Ribeiro, 1920) e Auchenipterus nuchalis (Spix \& Agassiz, 1829) no médio rio Xingu, no Estado do Pará, Brasil. Os indivíduos analisados foram coligidos por meio de capturas trimestrais entre os meses de abril de 2012 a janeiro de 2014 contemplando os quatro períodos hidrológicos (cheia, vazante, seca e enchente). A proporção sexual, o tamanho de primeira maturidade sexual, o índice gonadossomático e o fator de condição foram analisados para as duas espécies, e avaliados em função dos diferentes períodos hidrológicos. Foram coletados 897 espécimes de T. piresi, sendo 467 fêmeas e 430 machos, e 383 A. nuchalis, sendo 286 fêmeas e 97 machos. Para T. piresi a proporção sexual variou apenas nos períodos de enchente e vazante, enquanto que para $A$. nuchalis a proporção variou entre todos os períodos hidrológicos, com uma proporção maior de fêmeas do que machos. Em relação ao tamanho mínimo da primeira maturação sexual, as fêmeas de T. piresi maturam com tamanho inferior aos dos machos, enquanto que o inverso foi registrado para A. nuchalis. Para T. piresi a maior atividade reprodutiva foi registrada nos períodos de seca e enchente, enquanto que para $A$. nuchalis a maior atividade foi registrada na enchente e cheia. Machos e fêmeas de T. piresi não diferiram entre os padrões de crescimento, ambos apresentaram crescimento alométrico positivo. Já para A. nuchalis, o padrão de crescimento diferiu entre os sexos, embora ambos tenham apresentado crescimento alométrico negativo. Para as fêmeas de ambas as espécies foram observadas um maior fator de condição no período da vazante. 
Assim, nossos resultados evidenciam que o pulso de inundação pode influenciar de maneiras distintas os parâmetros reprodutivos destas duas espécies de auchenipterideos, pois a desolva de A. nuchalis parece acontecer no período de cheia e de T. piresi para a época de seca do Médio Rio Xingu.

Palavras-chave: Amazônia, Auchenipteridae, pulso de inundação, reprodução de peixes.

\section{Introduction}

Studies of the reproductive biology of fishes represent an important tool for the understanding of population dynamics in relation to the seasonal variation of the abiotic factors observed in aquatic ecosystems. In tropical rivers, this seasonality is molded primarily by fluctuations in rainfall levels and the associated hydrological oscillations of the flood pulse (Junk et al., 1989). As the river floods, the adjacent forests are inundated, increasing the augmentation of feeding resources and the formation of new habitats that can be used as spawning grounds and nurseries (Goulding, 1980; Junk et al., 1989; Lowe-McConnell, 1999).

The variation in the hydrological cycle also plays a significant role in the maturation of the gonads, spawning season, and the larval development of fish species (Goulding, 1980; Ruffino and Isaac, 1995; Zeug and Winemiller, 2008; Queiroz et al., 2010; Freitas et al., 2011; Maciel et al., 2011; Prudente et al., 2015). Spawning during the filling and flood season may contribute to reproductive success in many fish species (Godinho et al., 2010), due in particular to the increased availability of habitats that favour the survival of larvae and fry (Agostinho et al., 2004).

Studies of the reproductive biology of the Auchenipteridae fishes are relatively scant, given the considerable species richness of this family found in the Amazon basin (Ferraris Junior, 2003). In the case of Tocantinsia piresi (Miranda Ribeiro, 1920), for example, no published data are available on the biology or ecology of the species, and while Auchenipterus nuchalis (Spix, 1829) has been included in a number of community-level studies (Mérona, 1987; Leite et al., 2006; Melo and Lima, 2007), no data are available on the seasonality of breeding patterns in the Amazon. As a fishery resource, T. piresi has no information available and, according to Santos et al. (2006), A. nuchalis has an insignificant importance at one of the most important Amazonian fish markets.

The present study focuses on the reproductive characteristics of the populations of these two species on the middle Xingu River in the Brazilian Amazon basin. The study investigates the effects of the flood pulse on the gonadosomatic index (GSI), condition factor (K), and sex ratio; as well as providing information on the size at first gonadal maturity $\left(\mathrm{L}_{50}\right)$, length-weight relationships and type of growth. The study was based on the hypothesis that the reproductive parameters of both species reflect the seasonal dynamics of the flood pulse in the Xingu River.

\section{Material and Methods}

\subsection{Study area}

The present study was conducted on the middle Xingu River, specifically on the Bacajá ( $3^{\circ} 45^{\prime} 12^{\prime \prime}$ S, $\left.51^{\circ} 34^{\prime} 59^{\prime \prime} \mathrm{W}\right)$,

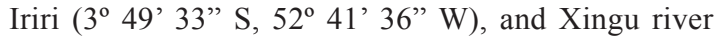
( $\left.3^{\circ} 12^{\prime} 52^{\prime \prime} \mathrm{S}, 52^{\circ} 11^{\prime} 23^{\prime \prime} \mathrm{W}\right)$ (Figure 1). The Xingu, a

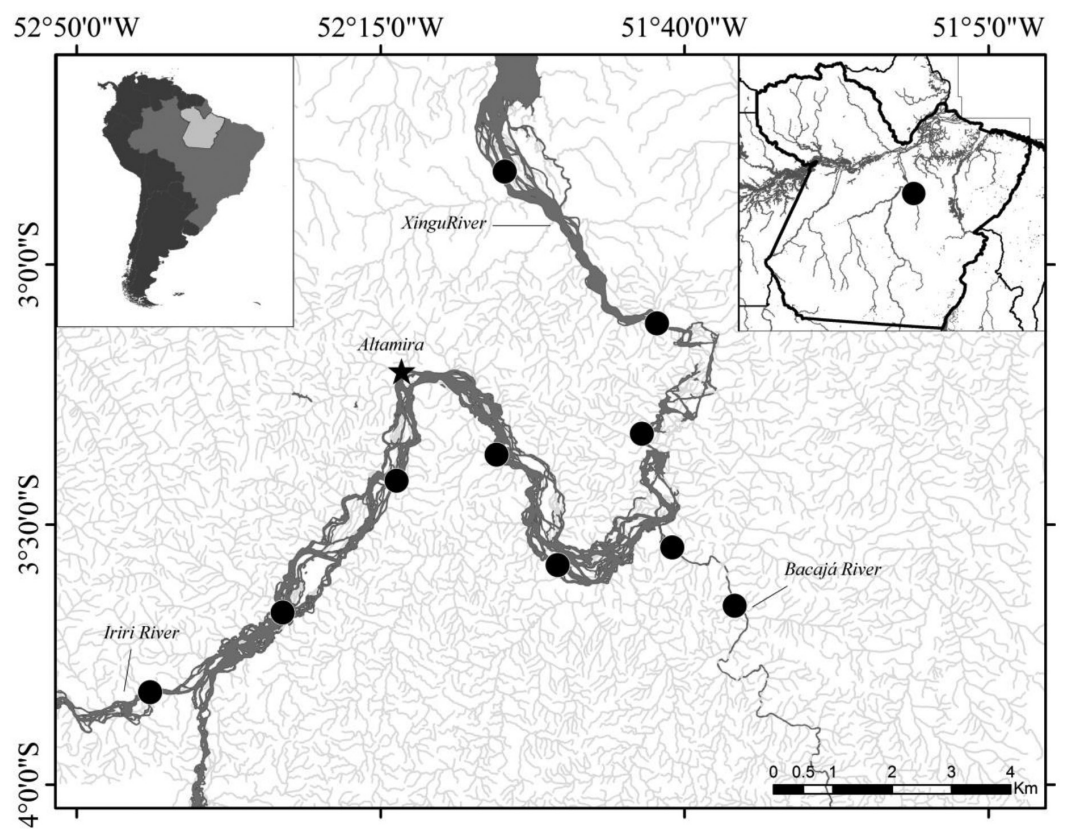

Figure 1. Study area on the middle Xingu River, Pará, Brazil. The black spots represent the sampling sites. 
clear water (low $\mathrm{pH}$, conductivity, and suspended solids), right-bank tributary of the Amazon, is 2,045 km long. The local climate is tropical hot and humid, of the Am subtype in the Köppen classification (Peel et al., 2007). During the study period (April 2012 to January 2014), monthly precipitation varied from $10.8 \mathrm{~mm}$ to $478.3 \mathrm{~mm}$ (INMET, 2014) in the region. Based on this pluviometric variation, four distinct hydrological periods were identified: ebb (June-August), dry (September-November), filling (December and February), and flood (March-May).

\subsection{Sampling strategy}

Specimens of T. piresi and A. nuchalis were collected every three months between April, 2012, and January, 2014, from the middle sections of the Xingu River. The fish were sampled according to the environmental monitoring guidelines of the Belo Monte dam, using gillnets of ten different mesh sizes (between $20 \mathrm{~mm}$ and $180 \mathrm{~mm}$ stretch mesh sizes), long lines with 30 hooks (size 12/0 and 14/0) cast under the guidance of a local fisherman and set for twelve hours per day.

Once captured, the specimens were weighed (total mass, $M_{T}$, to the nearest $0.01 \mathrm{~g}$ ), measured (standard length, $L_{s}$, to the nearest $0.1 \mathrm{~cm}$ ), and eviscerated through a longitudinal incision in the ventral region for the determination of sex and removal of the gonads, which were also weighed ( $M_{G}-$ mass in grams). Voucher specimens were fixed in $10 \%$ formalin solution for approximately $48 \mathrm{~h}$, transferred to $70 \%$ ethanol, and will be deposited in the Laboratório de Ictiologia de Altamira (LIA) in Altamira (Pará, Brazil).

\subsection{Biological parameters}

The sex ratios were examined for each hydrological season and the study period as a whole using Chi-square $\left(\chi^{2}\right)$, with the null hypothesis that the numbers of males and females were equal during each period. Males and females of both species were also evaluated for differences in length and weight by a t-test.

The size at first maturity $\left(\mathrm{L}_{50}\right)$ of each species was estimated applying the method proposed by Fontoura et al. (2010), which uses the Gonadosomatic Index (GSI) values. The GSI was obtained for each individual based on $G S I=M_{G} / M_{T} * 100$ (Vazzoler, 1996), where $M_{G}$ is the mass of the gonads and $M_{T}$ is the total mass of the individual. According to Fontoura et al. (2010), the GSI values were then converted into relative proportion of the maximum GSI value recorded. The method predicts that all individuals for which this proportion is equal or greater than a pre-established percentage were considered to be engaged in the reproductive process. Here we chose $5 \%$ as the critical value for defining reproductive status.

This approach is based on a modified logistic equation $P=A /\left(1+e^{\left(r\left(L_{S}-L_{50}\right)\right)}\right)$, where $P$ is the proportion of adult individuals in each length class, $r$ is a rate parameter related to the velocity of the change from juvenile to adult, $L_{s}$ is the standard length in centimetres, and $L_{50}$ is the mean length at first sexual maturity.
These parameters were estimated from the $A$. nuchalis data organised into $2 \mathrm{~cm}$ length classes, and the $T$. piresi data in $1 \mathrm{~cm}$ classes using non-linear functions in the SPSS ${ }^{\circledR}$ 17.0 software package (Levenberg-Marquardt algorithm). Length classes were defined after visual inspection of the histogram. Rare length classes $(\mathrm{n}<3)$ were discarded due to an inability to perform basic statistical procedures. The coefficient of determination was calculated as the ratio between the sum of the squares of the residuals and the total sum of squares (Zar, 2009). The p values were obtained by testing the significance of the coefficient of determination, using the F statistic (Zar, 2009). Differences in the size at first maturity between genders were assessed by a $t$ test (Zar, 2009).

The spawning season was identified through the analysis of the seasonal variation in the Gonadosomatic Index (GSI), including only those individuals of a size equal to or greater than that estimated for first maturity $\left(\mathrm{L}_{50}\right)$. The seasonal variation in the GSI was tested in relation to the different hydrological periods using the nonparametric Kruskal-Wallis analysis of variance $(\mathrm{H})$, followed by an $a$ posteriori Nemenyi multiple comparison test (Zar, 2009), based on the null hypothesis that there is no correlation between the variation in the GSI and the sample period.

The length-weight relationship adhered to the model first proposed by Järvi (1920) (see Froese, 2006), $M_{T}=a^{*} L_{S}^{b}$, where $M_{T}$ is the total mass of the specimen and $L_{S}$ its standard length. This equation also assumes that body proportions increase according to $a$ and $b$, defined as the coefficient of proportionality and the coefficient of allometry, respectively, where parameter $b$ can also be interpreted as the fish growth type (Froese, 2006).

To assess gender differences in growth pattern, we compared male and female residuals with the $t$ test, based on the comparison of morphological parameters, proposed by Fontoura and Conter (2008). To define the type of growth, the coefficient of alometry $(b)$ was evaluated by $t$ test, comparing the $b$ values obtained with a hypothetical $\mathrm{b}=3$, which define isometric growth (Froese, 2006).

The coefficient of proportionality $(a)$ can be described as the Condition Factor $(\mathrm{K})$, which was calculated for each individual by the deduced formula $K=\left(M_{T} / L_{S}{ }^{b}\right) * 100$, using the allometric coefficient $(b)$ obtained in the length-weight relationships, The seasonal variation in $\mathrm{K}$ was also assessed by the nonparametric Kruskal-Wallis $(\mathrm{H})$ test and followed by an a posteriori Nemenyi multiple comparison test (Zar, 2009), with the and the null hypothesis that the fish presented the same general condition among sample periods. All statistical tests were performed with a significant level of $5 \%$ (Zar, 2009).

\section{Results}

A total of 897 specimens of Tocantinsia piresi (467 females and 430 males) and 383 Auchenipterus nuchalis (286 females and 97 males) were collected during the present study. In $T$. piresi (Table 1), the sex ratio deviated significantly only in the filling $\left(\chi^{2}=4.56\right.$; 
$p=0.033)$ and ebb period $\left(\chi^{2}=9.52 ; p=0.002\right)$ of 2013, although the sex ratio for the study period as a whole was balanced $\left(\chi^{2}=1.53 ; \mathrm{p}=0.217\right)$. In A. nuchalis, by contrast, the sex ratio was significantly biased towards the females in almost all seasons (Table 1), and in general, by approximately three to one $\left(\chi^{2}=93.27 ; \mathrm{p}=0.000\right)$.

Males of $T$. piresi presented a mean standard length of $31.7 \mathrm{~cm}( \pm 6.0 \mathrm{~cm}, \min =11.9 \mathrm{~cm}, \max =46.0 \mathrm{~cm})$, slightly larger than the mean value recorded for the females $(31.0 \pm 4.4 \mathrm{~cm} ; \min =9.3 \mathrm{~cm} ; \max =44.5 \mathrm{~cm}$; $\mathrm{t}=-1.996 ; \mathrm{p}=0.023)$. In A. nuchalis, by contrast, the females were slightly larger than the males $(t=1.736$; $\mathrm{p}=0.042)$, with a mean standard length equal to $12.7 \mathrm{~cm}$ $( \pm 2.2 \mathrm{~cm}, \min =8.1 \mathrm{~cm}, \max =19.5 \mathrm{~cm})$ and $12.3( \pm 1.7 \mathrm{~cm}$; $\min =8.5 \mathrm{~cm}, \max =16.0 \mathrm{~cm})$, respectively.

For weight, males of $T$. pires $i$ were slightly greater than females $(\mathrm{t}=-3.142 ; \mathrm{p}=0.001)$, showing the mean weight equal to $846.6 \mathrm{~g}( \pm 444.5 \mathrm{~g}$; $\min =28.2 ; \max =2400.0)$ and $765.3 \mathrm{~g}( \pm 313.0 \mathrm{~g}$; $\min =14.4 \mathrm{~g}$; $\max =2145.0 \mathrm{~g})$, respectively. For $A$. nuchalis, females were heavier than males $(\mathrm{t}=2.973 ; \mathrm{p}=0.002)$. The mean weight of females was $25.2 \mathrm{~g}( \pm 14.0 \mathrm{~g}$; $\min =7.0 \mathrm{~g}$; $\max =79.0 \mathrm{~g})$ and males was $21.4 \mathrm{~g}$ ( $\pm 9.8 \mathrm{~g}$; $\min =7.4 \mathrm{~g}$; $\max =57.0 \mathrm{~g})$.

Female of $T$. piresi presented a smaller mean size at first sexual maturity $\left(L_{50}\right)$ than males $(\mathrm{t}=5.432 ; \mathrm{p}=0.000)$. Females reached maturity with $33.76 \mathrm{~cm}\left( \pm 0.35 ; \mathrm{R}^{2}=0.99\right.$; $\mathrm{F}=542.98 ; \mathrm{p}=0.000 ;$ Figure $2 \mathrm{a})$, while males attained maturity with $34.84 \mathrm{~cm}\left( \pm 0.596 ; \mathrm{R}^{2}=0.98 ; \mathrm{F}=185.47\right.$; $\mathrm{p}=0.001$; Figure 2b). In contrast, the mean size at first maturity of females of $A$. nuchalis was higher than males $(\mathrm{t}=18,676 ; \mathrm{p}=0.000)$. Thus, the $L_{50}$ of females was $13.98 \mathrm{~cm}\left(\mathrm{R}^{2}=0.99 ; \mathrm{F}=228.52 ; \mathrm{p}=0.000\right.$; Figure $\left.2 \mathrm{c}\right)$ and for males was $10.85 \mathrm{~cm}\left(\mathrm{R}^{2}=0.98 ; \mathrm{F}=88.64 ; \mathrm{p}=0.002\right.$; Figure 2d).

In $T$. piresi, both sexes presented greater gonadal activity (GSI) during low water, extending into the flood season, but less intensively (Figure 3a-b). The GSI of females varied significantly among periods $\left(\mathrm{H}_{(6, \mathrm{~N}=122)}=88.29\right.$ $\mathrm{p}=0.000)$. The higher GSI values recorded during the dry season for females were significantly different from those recorded in other periods $(\mathrm{p}<0.05)$ except the filling season of 2012, when some mature specimens were still collected. In the males, the GSI also varied significantly among hydrological periods $\left(\mathrm{H}_{(5, \mathrm{~N}=87)}=33.20 \mathrm{p}=0.000\right)$. However, only the values recorded at dry season in 2013 (October) were different from other hydrological periods $(\mathrm{p}>0.05)$.

In A. nuchalis, the GSI values for both females and males indicated greater gonadal activity during the filling and flood seasons, with earlier maturation in males (Figure 3c-d). Significant variation in GSI values was observed in females $\left(\mathrm{H}_{(4, \mathrm{~N}=71)}=33.62 ; \mathrm{p}=0.000\right)$ although the lowest GSI values at the dry season of 2013 differed from the others periods $(\mathrm{p}>0.05)$. Males of A. nuchalis also had significant variation in GSI values among hydrological periods $\left(\mathrm{H}_{(4, \mathrm{~N}=73)}=13.08 ; \mathrm{p}=0.010\right)$, with the highest GSI values at the filling season differing from the other periods.

No differences in growth patterns were found in the residual morphometric parameters of males and females of T. piresi $(t=0.685 ; \mathrm{df}=895 ; \mathrm{p}=0.247)$, and the analysis continued with the unified sexes. Thus, this species presented a coefficient of alometry (b) equal to 3.09 , and showed a positive allometric growth $(\mathrm{t}=3.091 ; \mathrm{p}<0.001)$.

Table 1. Sex ratio in the Tocantinsia piresi and Auchenipterus nuchalis specimens collected from the middle Xingu River between April, 2012, and January, 2014.

\begin{tabular}{|c|c|c|c|c|c|c|c|c|}
\hline \multirow{2}{*}{\multicolumn{3}{|c|}{ Year/ hydrological period/sex }} & \multicolumn{3}{|c|}{ Tocantinsia piresi } & \multicolumn{3}{|c|}{ Auchenipterus nuchalis } \\
\hline & & & $\mathbf{N}$ & $\chi^{2}$ & $\mathbf{P}$ & $\mathbf{N}$ & $\chi^{2}$ & $\mathbf{p}$ \\
\hline \multirow{6}{*}{2012} & \multirow{2}{*}{ Flood } & Female & 44 & \multirow{2}{*}{0.80} & \multirow{2}{*}{0.371} & 13 & \multirow{2}{*}{10.29} & \multirow{2}{*}{0.001} \\
\hline & & Male & 36 & & & 1 & & \\
\hline & \multirow{2}{*}{ Ebb } & Female & 4 & \multirow{2}{*}{2.02} & \multirow{2}{*}{0.155} & 8 & \multirow{2}{*}{-} & \multirow{2}{*}{ - } \\
\hline & & Male & 3 & & & 0 & & \\
\hline & \multirow{2}{*}{ Dry } & Female & 13 & \multirow{2}{*}{1.80} & \multirow{2}{*}{0.180} & 36 & \multirow{2}{*}{9.68} & \multirow{2}{*}{0.002} \\
\hline & & Male & 7 & & & 14 & & \\
\hline \multirow{8}{*}{2013} & \multirow{2}{*}{ Filling } & Female & 100 & \multirow{2}{*}{4.56} & \multirow{2}{*}{0.033} & 60 & \multirow{2}{*}{20.00} & \multirow{2}{*}{0.000} \\
\hline & & Male & 72 & & & 20 & & \\
\hline & \multirow{2}{*}{ Flood } & Female & 158 & \multirow{2}{*}{0.01} & \multirow{2}{*}{0.910} & 47 & \multirow{2}{*}{2.09} & \multirow{2}{*}{0.147} \\
\hline & & Male & 156 & & & 34 & & \\
\hline & \multirow{2}{*}{$\mathrm{Ebb}$} & Female & 31 & \multirow{2}{*}{9.52} & \multirow{2}{*}{0.002} & 3 & \multirow{2}{*}{-} & \multirow[b]{2}{*}{ - } \\
\hline & & Male & 11 & & & 0 & & \\
\hline & & Female & 13 & & & 79 & & \\
\hline & Dry & Male & 17 & 0.53 & 0.465 & 6 & 62.69 & 0.000 \\
\hline & & Female & 104 & & & 40 & 523 & \\
\hline 2014 & F1lling & Male & 128 & 2.48 & 0.115 & 22 & 5.23 & 0.022 \\
\hline & & Female & 467 & 153 & 0217 & 286 & 0327 & 00000 \\
\hline & & Male & 430 & 1.53 & 0.217 & 97 & 93.21 & 0.000 \\
\hline
\end{tabular}



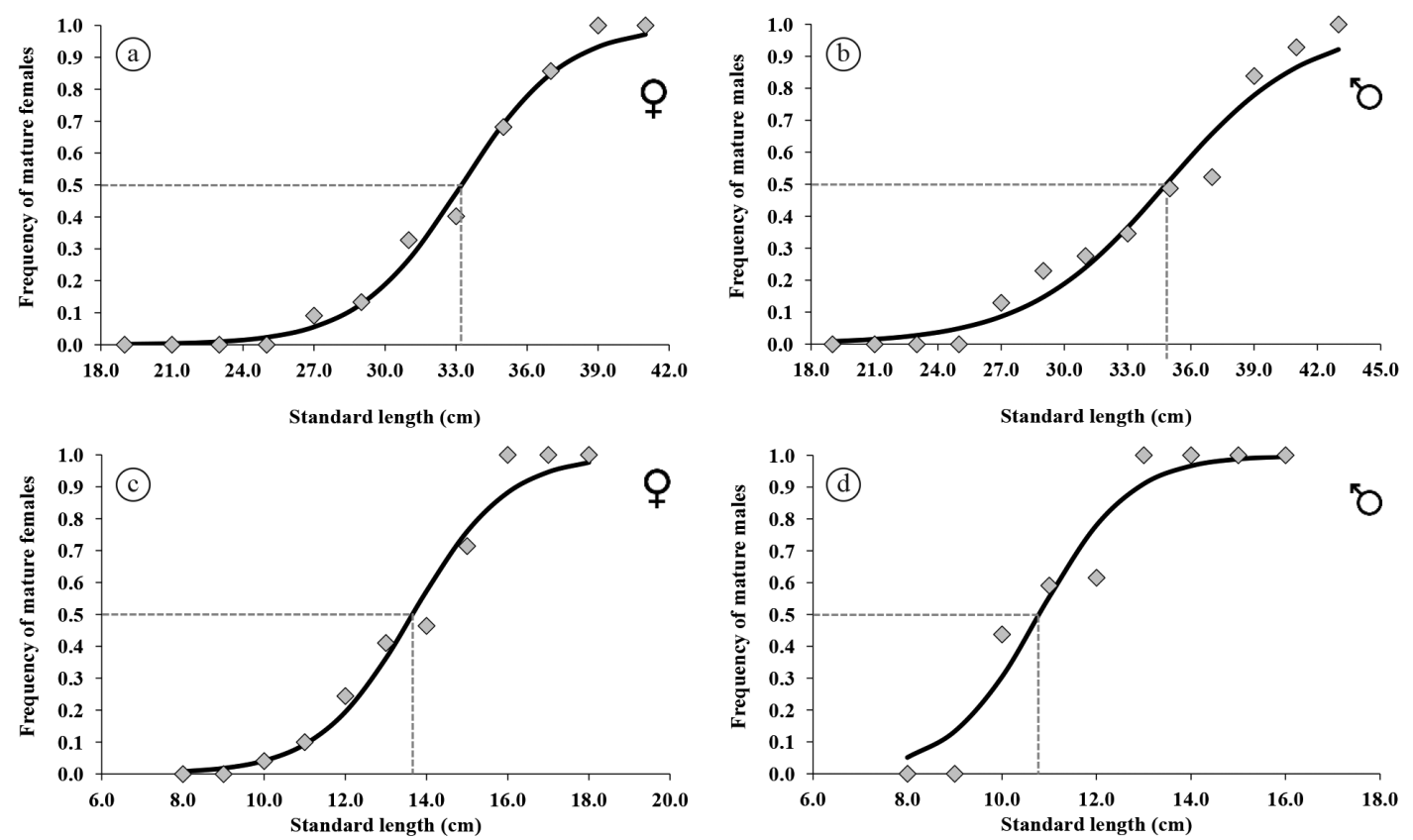

Figure 2. Frequency of mature Tocantinsia piresi (a - Female; b-Male) and Auchenipterus nuchalis (c-Female; d-Male) specimens collected from the middle Xingu River between April, 2012, and January, 2014.
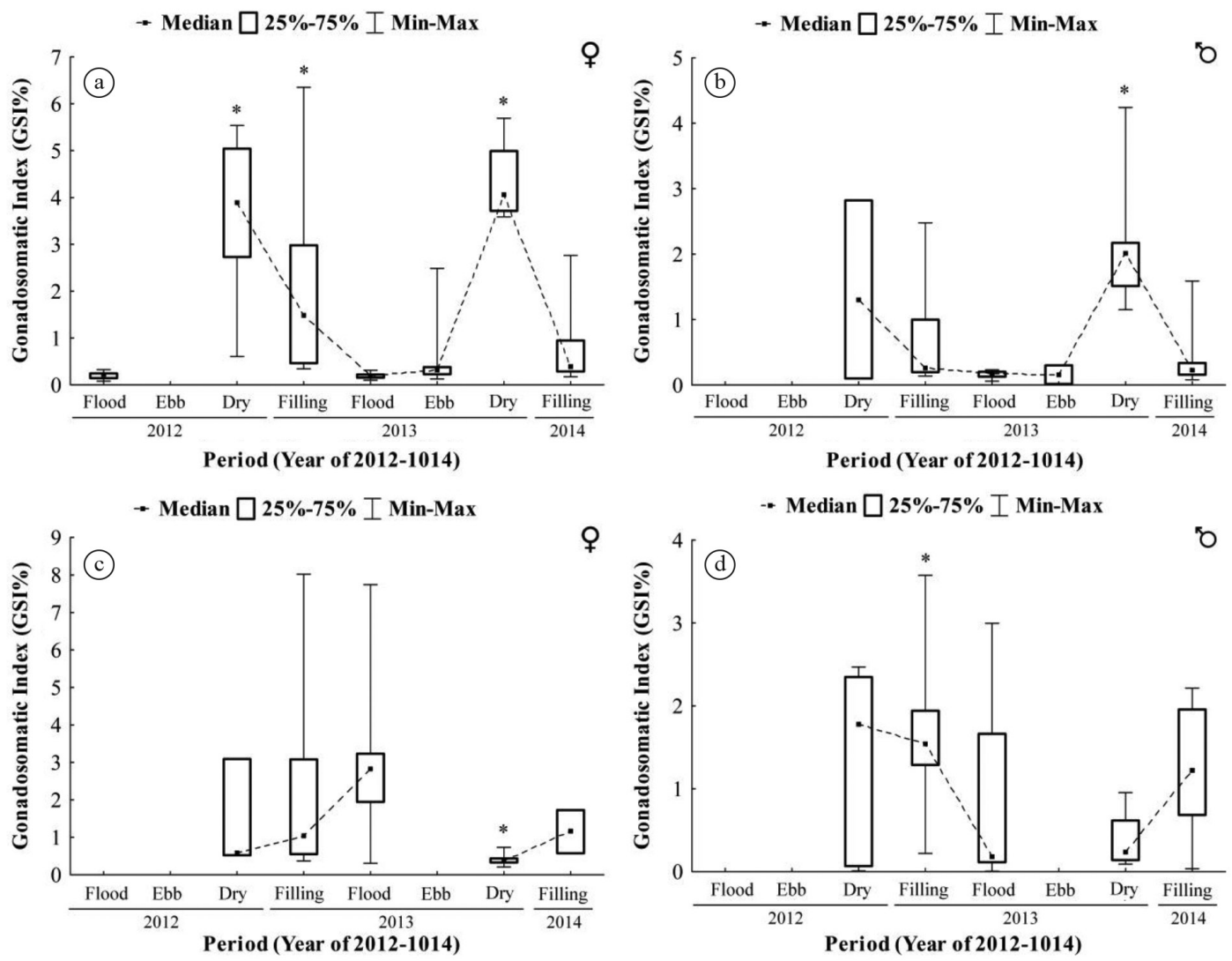

Figure 3. Seasonal variation in the Gonadosomatic Index (GSI) for female (a) and male (b) Tocantinsia piresi and female (c) and male (d) Auchenipterus nuchalis specimens collected from the middle Xingu River between April, 2012, and January, 2014. * indicates significant differences from other periods. 
The length-weight equation established for T. piresi was $M_{T}=0.017 * L_{S}^{3.09}$.

In A. nuchalis, residual analysis of the morphometric parameters evidenced a distinct growth patterns between males and females $(t=2.740 ; \mathrm{df}=381 ; \mathrm{p}=0.003)$. Both genders showed negative alometry; females present $b=2.74$ $(\mathrm{t}=5.532 ; \mathrm{p}<0.001)$ and males $\mathrm{b}=2.51(\mathrm{t}=4.721$; $\mathrm{p}<0.001)$. In this case, the length-weight relationship for females and males of $A$. nuchalis was $M_{T}=0.022 * L_{S}{ }^{2.74}$ and $M_{T}=0.037 * L_{S}{ }^{2.51}$, respectively. Length-weight relationship parameters for both species are summarised in Table 2.
The condition factor $(\mathrm{K})$ varied among hydrological periods in both species. In female $T$. piresi the $\mathrm{K}$ values varied among hydrological seasons $\left(\mathrm{H}_{(7, \mathrm{~N}=467)}=99.07\right.$; $\mathrm{p}=0.000$; Figure $4 \mathrm{a})$. The highest values recorded during the flood and ebb seasons of 2012 contrasted significantly from the others periods $(\mathrm{p}>0.05)$ The condition factor also varied significantly among seasons in the male $T$. pires $i$ $\left(\mathrm{H}_{(7, \mathrm{~N}=430)}=87.17 ; \mathrm{p}=0.000\right.$; Figure $\left.4 \mathrm{~b}\right)$, with the highest values being recorded during the flood and ebb seasons of 2012. The $\mathrm{K}$ values obtained at the flood 2012 and filling 2013 differed from the others hydrological season $(p>0.05)$.

The condition factor also varied seasonally in both sexes of $A$. nuchalis. In the females, the highest values

Table 2. Length-weight relationship of the Tocantinsia piresi and Auchenipterus nuchalis specimens collected from the middle Xingu River between April, 2012, and January, 2014. Estimated $a$ and $b$ values are shown with their respective confidence intervals $(95 \%)$ and determination coefficients $\left(\mathrm{R}^{2}\right)$.

\begin{tabular}{ccccc}
\hline \multirow{2}{*}{ Species } & \multirow{2}{*}{ Sex } & \multicolumn{2}{c}{ Estimated Parameter } & \multirow{2}{*}{$\mathbf{R}^{\mathbf{2}}$} \\
\cline { 2 - 5 } & & $\boldsymbol{a}(\mathbf{9 5 \%} \mathbf{C I})$ & $\boldsymbol{b} \mathbf{( 9 5 \% \mathbf { C I } )}$ & \\
\hline Tocantinsia piresi & Female/Male & $0.017(0.013-0.021)$ & $3.095(3.035-3.155)$ & 0.915 \\
\hline \multirow{2}{*}{ Auchenipterus nuchalis } & Female & $0.022(0.017-0.027)$ & $2.740(2.647-2.833)$ & 0.926 \\
\cline { 2 - 5 } & Male & $0.037(0.019-0.055)$ & $2.509(2.302-2.716)$ & 0.865 \\
\hline
\end{tabular}
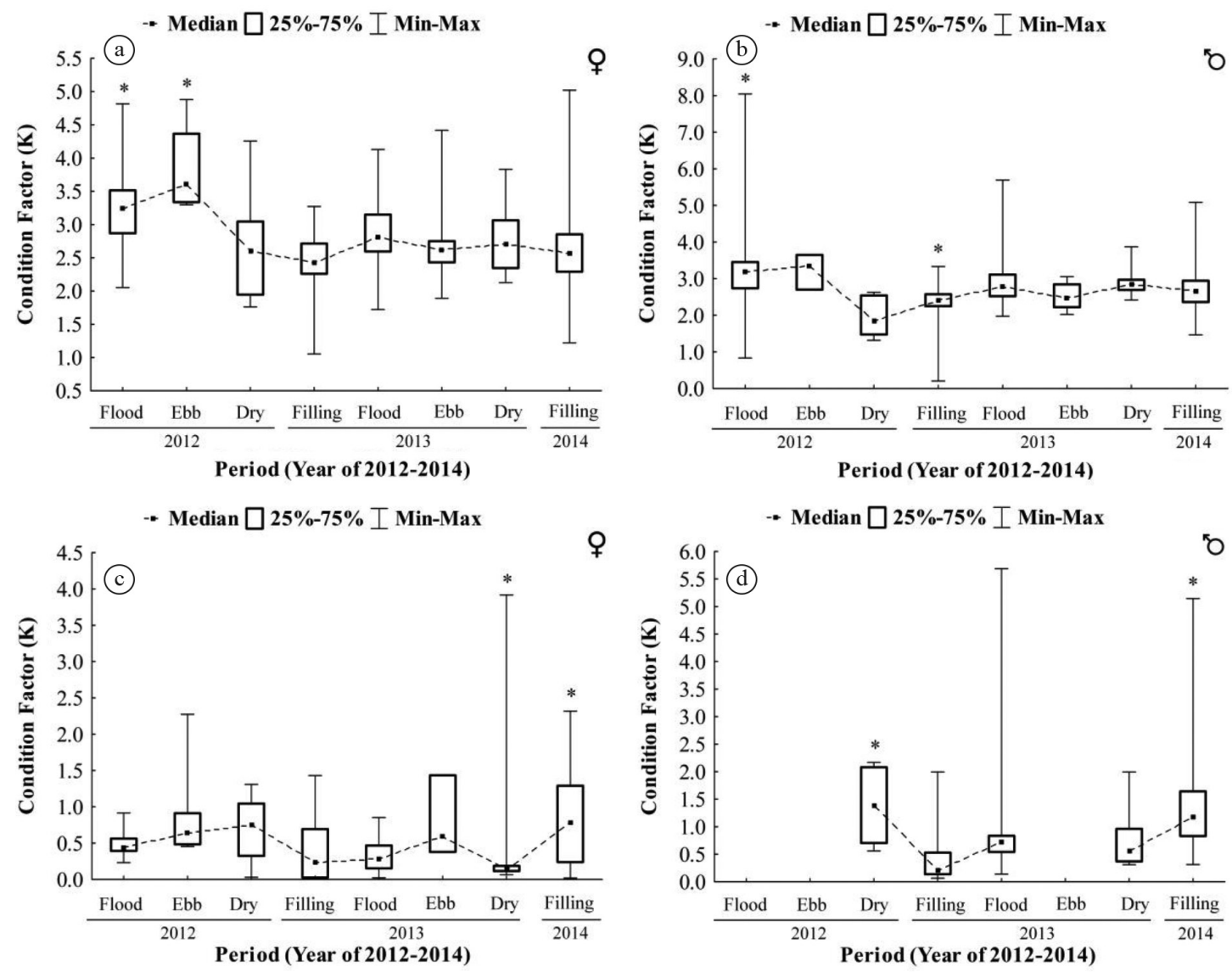

Figure 4. Seasonal variation in the condition factor (K) of female (a) and male (b) Tocantinsia piresi and female (c) and male (d) Auchenipterus nuchalis specimens collected from the middle Xingu River between April, 2012, and January, 2014. * indicates significant differences from other periods. 
were recorded during the filling season $\left(\mathrm{H}_{(7, \mathrm{~N}=286)}=83.97\right.$; $\mathrm{p}=0.000$; Figure 4c). In male A. nuchalis, the condition factor showed the highest values during the dry season of 2012 and filling season of $2013\left(\mathrm{H}_{(4, \mathrm{~N}=96)}=36.05 ; \mathrm{p}=0.000\right.$; Figure $4 d$ ). Both males and females present $\mathrm{K}$ values in the dry and filling season that differed significantly from the others periods.

\section{Discussion}

Some recent studies have focused on reproductive parameters in a small number of auchenipterid species (Freitas et al., 2011; Maia et al., 2013; Santos et al., 2013). The present study provides the first published data on the biology of Tocantinsia piresi.

While a predominance of females was recorded in A. nuchalis, no bias was found in T. piresi, although the high water period of 2013 was the only season when females were not in the majority. Deviations in sex ratios may be related to a series of factors, such as genetic variation, growth and mortality rates, behaviour patterns, variations in environmental conditions, and even the selectivity of capture method (Nikolsky, 1969; Vazzoler, 1996; Agostinho et al., 2007; Prudente et al., 2015).

The variation observed in the sex ratio of $A$. nuchalis may be related to spatial sexual segregation, although this distinction was not observed during the flood season, when reproduction peaked (see below). A predominance of females has been observed in other auchenipterids (Araujo et al., 1999; Becker, 2001; Freitas et al., 2011; Maia et al., 2013) and may be the result of population-level strategies adopted for the optimisation of reproductive success, given that males can fertilise more than one female (Burgess, 1989).

The size of male $T$. pires $i$ at first maturity was greater than that of the females, an unusual pattern in tropical fishes, although larger males at first maturity are often observed in some cichlid species (Camara et al., 2002; Souza et al., 2008) because their reproductive behaviour, such as competition for spawning, parental care, and mate choice, is based mainly on criteria of size and colour (Lowe McConnell, 1969; Muñoz et al., 2006). Given this, the larger size of the $T$. piresi males may be related to reproductive strategies such as mate choice and spawning site selection. As nothing is known of the reproductive behaviour, growth or population dynamics of this species, additional research will be required in order to better understand this phenomenon.

In A. nuchalis, females matured at larger sizes than males, a pattern found in other auchenpterids (Freitas et al., 2011; Santos et al., 2013) as well as many other tropical fishes (Barbieri et al., 2004; Nunes et al., 2004; Gomiero et al., 2007; Rodrigues-Filho et al., 2011; Prudente et al., 2015). In this case, size differences between males and females at first maturity may be related to reproductive competition, with males investing in early maturation in order to be ready to reproduce as soon as possible, ensuring the perpetuation of their genes. In females, greater size at first maturity may be related to their increased energy requirements for gonadal maturation (Bromley, 2003).

The GSI values reflected seasonal patterns of reproduction in both study species. In $T$. piresi, gonadal activity peaked mainly in the dry season, which is distinct from the data available for other auchenipterid species (Araujo et al., 1999; Silva and Viana, 2003; Freitas et al., 2011; Maia et al., 2013; Santos et al., 2013). A reproductive peak in the dry season may be related to a strategy for the selection of spawning sites. According to local fishermen, T. piresi is hard to catch with gillnets at low water because these fish are hidden in rocky crevices in the river bottom, but are easy to capture during the filling and high flood. The evidence suggests that the species spawns and raises its offspring in these rocky crevices during low water, and then move to the floodplains during high water to feed and grow.

In $A$. nuchalis, the highest GSI values were recorded in different periods for the two sexes, i.e., the dry/filling season in the males and flood period for females. Freitas et al. (2011) observed asynchronous GSI peaks in Auchenipterichthys longimanus (Günther, 1864), which may be related to the insemination strategy, with a temporal gap between copulation and spawning because fertilisation takes place only when the female deposits the eggs, without male participation, using stored sperm (Burgess, 1989; Azevedo et al., 2000; Melo et al., 2011; Santos et al., 2013).

The filling and flood periods appear to be the most favourable for fish reproduction (Goulding, 1980), given that the flooded forest provides a wealth of habitats for feeding, refuges from predators, and nursery areas. The role of the flood pulse in fish reproduction has been discussed by a number of authors (Zeug and Winemiller, 2008; Bailly et al., 2008; Prudente et al., 2015).

The length-weight relationship was positively allometric in $T$. piresi, but negatively allometric in A. nuchalis. Distinct growth patterns in males and females were only observed in A. nuchalis. Negative allometry means that length increases at a faster rate than the weight (Froese, 2006), and the relatively more negative allometry recorded in the males in comparison with the females may reflect a strategy of achieving maturity early in order to better compete with other males for access to reproductive females.

Seasonal variation in the condition factor $(\mathrm{K})$ was recorded in both species, and was more accentuated in the females. Higher mean $\mathrm{K}$ values were recorded in T. piresi and female A. nuchalis during the ebb season, while lower values were found primarily during the dry and filling periods. The condition factor is a quantitative index of the physiological characteristics of fishes (Le Cren, 1951), and reflects the energy balance between weight and growth, and their relationship with the reproductive and nutritional characteristics of fish species (Vazzoler, 1996; Araujo and Vicentini, 2001; Lima-Júnior and Goitein, 2006; Gomiero et al., 2012).

The seasonal variation observed in the condition factor in the present study is consistent with that found in other auchenipterids (Araujo et al., 1999; Freitas et al., 2011), 
in which $\mathrm{K}$ values are sometimes inversely proportional to those of the gonadosomatic index (GSI). These results indicate a joint effect of feeding and reproduction on the physiological condition of the species. The filling season permits more intense feeding due the nutrients available on the floodplain (Goulding, 1980), resulting in an increase in $\mathrm{K}$ values, while the reproductive peak results in an increase in the expenditure of energy as well as a reduction in feeding intensity.

In $T$. piresi, in addition to the energy invested in gonadal maturation, the reduced condition factor following the reproductive peak may be related to spawning events and the consequent reduction in weight. In the males of both species the lack of variation in the condition factor may be related to the reduced energetic investment in gonadal maturation.

Overall, the results of the present study indicate that the flood pulse may have differential effects on the recruitment patterns of the two studied species. However, the dynamics of this flood pulse will probably be modified drastically over the next few years as a result of changes in river discharge patterns caused by the implantation of hydroelectric projects. The effects of impoundment have generated considerable interest in fish biologists, due to the potential for the creation of novel environments and new patterns of community structure and function (Agostinho et al., 2008; Sabinson et al., 2014). The present study provides important data on the biology of the populations of two fish species prior to the flooding of the Belo Monte reservoir, and an important benchmark for the understanding of subsequent changes in these characteristics.

\section{Acknowledgements}

The authors are grateful to Norte Energia and LEME for financial support. Biological material was authorised by permit 057/2012 from IBAMA-Instituto Brasileiro de Meio Ambiente e de Recursos Naturais Renováveis. LFAM receives a productivity grant from $\mathrm{CNPq}$ (process: 301343/2012-8), VAO was funded by the Coordenação de Aperfeiçoamento de Pessoal de Nível Superior (CAPES), and BSP was funded by CNPq (process: 140160/2013-2). We also thank Nelson F. Fontoura for statistical and methodological assistance and all members of the IctioXingu CNPq Research Group and Dr. Stephen Ferrari for his help in correcting text, particularly the English.

\section{References}

AGOSTINHO, AA., GOMES, LC. and PELICICE, FM., 2007. Ecologia e manejo de recursos pesqueiros em reservatórios do Brasil. Maringá: EDUEM.

AGOSTINHO, AA., GOMES, LC., VERÍSSIMO, SV. and OKADA, EK., 2004. Flood regime, dam regulation and fish in the Upper Paraná River: effects on assemblage attributes, reproduction and recruitment. Reviews in Fish Biology and Fisheries, vol. 14, no. 1, p. 11-19. http://dx.doi.org/10.1007/s11160-004-3551-y.
AGOSTINHO, AA., PELICICE, FM. and GOMES, LC., 2008. Dams and the fish fauna of the Neotropical region: impacts and management related to diversity and fisheries. Brazilian Journal of Biology $=$ Revista Brasileira de Biologia, vol. 68, no. 4, supplement, p. 1119-1132. http://dx.doi.org/10.1590/S151969842008000500019. PMid:19197482.

ARAÚJO, FG. and VICENTINI, RN., 2001. Relação pesocomprimento da corvina Micropogonias furnieri (Desmarest) (Pisces, Sciaenidae) na Baía de Sepetiba, Rio de Janeiro. Revista Brasileira de Zoologia, vol. 18, no. 1, p. 133-138. http://dx.doi. org/10.1590/S0101-81752001000100014.

ARAÚJO, FG., DUARTE, S., GOLDBERG, RS. and FICHBERG, I., 1999. Indicadores reprodutivos de Parauchenipterus striatulus (Steindachner) (Pisces, Auchenipteridae) na Represa de Ribeirão das Lajes, Rio de Janeiro, Brasil. Revista Brasileira de Zoologia, vol. 16, no. 4, p. 1071-1079. http://dx.doi.org/10.1590/S010181751999000400016.

AZEVEDO, MA., MALABARBA, LR. and FIALHO, CB., 2000. Reproductive biology of the inseminated Glandulocaudine Diapoma speculiferum Cope (Actinopterygii: Characidae). Copeia, vol. 2000, no. 4, p. 983-989. http://dx.doi.org/10.1643/00458511(2000)000[0983:RBOTIG]2.0.CO;2.

BAILly, D., AGOSTINHO, AA. and SUZUKI, HI., 2008. Influence of the flood regime on the reproduction of fish species with different reproductive strategies in the Cuiabá River, Upper Pantanal, Brazil. River Research and Applications, vol. 24, no. 9, p. 1218-1229. http://dx.doi.org/10.1002/rra.1147.

BARBIERI, G., SALLES, FA., CESTAROLli, MA. and TEIXEIRA-FILHO, RA., 2004. Estratégias reprodutivas do dourado, Salminus maxillosus e do curimbatá, Prochilodus lineatus no Rio Mogi Guaçu, Estado de São Paulo, com ênfase nos parâmetros matemáticos da dinâmica populacional. Acta Scientiarum. Biological Sciences, vol. 26, no. 2, p. 169-174. http://dx.doi.org/10.4025/actascibiolsci.v26i2.1631.

BECKER, FG., 2001. Observations on the reproduction, sex ratio and size composition of Trachelyopterus lucenai (Teleostei, Auchenipteridae) in lake Guaíba, RS, Brazil. Biociencias, vol. 9, no. 2, p. 85-96.

BROMLEY, JP., 2003. The use of market sampling to generate maturity ogives and to investigates growth, sexual dimorphism and reproductive strategy in central and south-western North Sea sole (Solea solea L.). ICES Journal of Marine Science, vol. 60, no. 1, p. 52-65. http://dx.doi.org/10.1006/jmsc.2002.1318.

BURGESS, WE., 1989. An atlas of freshwater and marine catfishes: a preliminary survey of the Siluriformes. New Jersey: T.F.H. Publication. 784 p.

CAMARA, MR., CHELLAPA, NT. and CHELLAPA, S., 2002. Ecologia reprodutiva do Cichla monoculus, um ciclídeo amazônico no semi-árido do Rio Grande do Norte. Acta Limnologica Brasiliensis, vol. 14, no. 2, p. 9-16.

FERRARIS JUNIOR, CJ., 2003. Family Auchenipteidae. In REIS, RE., KULLANDER, SO. and FERRARIS JUNIOR, CJ. Check List of the Freshwater Fishes of South and Central America. Porto Alegre: EDIPUCRS. p. 470-482.

FONTOURA, NF. and CONTER, MR., 2008. Description of a new subspecies of the crayfish Parastacus brasiliensis (Von Martens, 1869) from São Francisco de Paula, RS, Brazil (Decapoda, Parastacidae). Zootaxa, vol. 1849, p. 28-34. 
FONTOURA, NF., JESUS, AS., LARRE, GG. and PORTO, JR., 2010. Can weight/length relationship predict size at first maturity? A case study with two species of Characidae. Neotropical Ichthyology, vol. 8, no. 4, p. 835-840. http://dx.doi.org/10.1590/ S1679-62252010005000013.

FREITAS, TMS., ALMEIDA, VHC., MONTAG, LFA., ROCHA, RM. and FONTOURA, NF., 2011. Seasonal changes in the gonadossomatic index, allometric condition factor and sex ratio of an auchenipterid catfish from eastern Amazonia. Neotropical Ichthyology, vol. 9, no. 4, p. 839-847. http://dx.doi.org/10.1590/ S1679-62252011005000044.

FROESE, R., 2006. Cube law, condition factor and weight-length relationships: history, meta-analysis and recommendations. Journal of Applied Ichthyology, vol. 22, no. 4, p. 241-253. http://dx.doi. org/10.1111/j.1439-0426.2006.00805.x.

GODINHO, AL., LAMAS, IR. and GODINHO, HP., 2010. Reproductive ecology of Brazilian freshwater fishes. Environmental Biology of Fishes, vol. 87, no. 2, p. 143-162. http://dx.doi. org/10.1007/s10641-009-9574-4.

GOMIERO, LM., SOUZA, UP. and BRAGA, FMS., 2007. Reprodução e alimentação de Rhamdia quelen (Quoy and Gaimard, 1824) em rios do Núcleo Santa Virgínia, Parque Estadual da Serra do Mar, São Paulo, SP. Biota Neotropica, vol. 7, no. 3, p. 127-133. http://dx.doi.org/10.1590/S1676-06032007000300015.

GOMIERO, LM., SOUZA, UP. and BRAGA, FMS., 2012. Condition factor of Astyanax intermedius Eigenmann, 1908 (OSTEICHTHYES, CHARACIDAE) parasitised by Paracymothoa astyanaxi Lemos de Castro, 1955 (CRUSTACEA, CYMOTHOIDAE) in the Grande River, Serra do Mar State Park - Santa Virgínia Unit, São Paulo, Brazil. Brazilian Journal of Biology $=$ Revista Brasileira de Biologia, vol. 72, no. 2, p. 379-388. http://dx.doi.org/10.1590/ S1519-69842012000200020. PMid:22735147.

GOULDING, M., 1980. The fishes and Forest: explorations in Amazon natural history. Berkeley: University of Califórnia Press. 280 p.

Instituto Nacional de Meteorologia - INMET, 2014. Banco de Dados Meteorológicos para Ensino e Pesquisa. Brasília. Available from: $<$ http://www.inmet.gov.br/portal/index.php?r=bdmep/ bdmep>. Access in: 7 Apr. 2014.

JÄRVI, TH., 1920. Die kleine Marane (Coregonus albula L.) im Kei- telesee, eine okologische und okonomische Studie. Suomalainen Tiedeakatemia Toimituksia. Sar. A.4: Biologica, vol. 14, no. 1, p. 1-302.

JUNK, WJ., BAYLEY, PB. and SPARKS, RE., 1989. The flood pulse concept in river-floodplain systems. Canadian Journal of Fishers and Aquatic, vol. 106, p. 110-127.

LE CREN, ED., 1951. The length - weight relationship and seasonal cycle in gonad weight and condition in the perch (Perca fluviatilis). Journal of Animal Ecology, vol. 20, no. 2, p. 201-219. http://dx.doi.org/10.2307/1540.

LEITE, RG., SILVA, JVV. and FREITAS, CE., 2006. Abundância e distribuição de larvas de peixes no Lago Catalão e na confluência dos rios Solimões e Negro, Amazônia, Brasil. Acta Amazonica, vol. 36 , no. 4 , p. 557-562. http://dx.doi.org/10.1590/S004459672006000400018

LIMA-JÚNIOR, SE. and GOITEIN, R., 2006. Fator de condição e ciclo gonadal de fêmeas de Pimelodus maculatus (Osteichthyes, Pimelodidae) no rio Piracicaba (SP, Brasil). Boletim do Instituto de Pesca, vol. 32, no. 1, p. 87-94.
LOWE-MCCONNELL, RH., 1969. The cichlid fishes of Guyana, South America, with notes on their ecology and breeding behaviour. Zoological Journal of the Linnean Society, vol. 48, no. 2, p. 255-302. http://dx.doi.org/10.1111/j.1096-3642.1969.tb00714.x.

LOWE-MCCONNELL, RH., 1999. Estudos ecológicos de comunidades de peixes tropicais. São Paulo: EDUSP. 534 p.

MACIEL, HM., SOARES, MGM. and PRESTES, L., 2011. Reprodução da piranha-amarela Serrasalmus spilopleura Kner, 1858, em lagos de várzea, Amazonas, Brasil. Biota Neotropica, vol. 11, no. 2, p. 2-6. http://dx.doi.org/10.1590/S1676-06032011000200011.

MAIA, RM., ARTIOLI, LGS. and HARTZ, SM., 2013. Diet and reproductive dynamics of Trachelyopterus lucenai (Siluriformes: Auchenipteridae) in subtropical coastal lagoons in southern Brazil. Zoologia, vol. 30, no. 3, p. 255-265. http://dx.doi.org/10.1590/ S1984-46702013000300002.

MELO, CE. and LIMA, J., 2007. Diversidade de espécies e influência de fatores estocásticos na regulação da ictiofauna em lagos de meandro na Bacia do Rio das Mortes, Mato Grosso, Brasil. Revista da Sociedade de Ecologia do Brasil, vol. 10, no. 2 , p. 22-27.

MELO, RMC., ARANTES, FP., SATO, Y., SANTOS, JE., RIZZO, E. and BAZZOLI, N., 2011. Comparative morphology of the gonadal structure related to reproductive strategies in six species of Neotropical Catfishes (Teleostei: Siluriformes). Journal of Morphology, vol. 272, no. 5, p. 525-535. http://dx.doi. org/10.1002/jmor.10931. PMid:21246599.

MÉRONA, B., 1987. Aspectos ecológicos da ictiofauna no baixo Tocantins. Acta Amazonica, vol. 16/17, p. 104-109.

MUÑOZ, H., VAN DAMME, PA. and DUPONCHELLE, F., 2006. Breeding behaviour and distribution of the tucunaré Cichla aff. monoculus in a clear water river of the Bolivian Amazon. Journal of Fish Biology, vol. 69, no. 4, p. 1018-1030. http:// dx.doi.org/10.1111/j.1095-8649.2006.01177.x.

NIKOLSKY, GV., 1969. Theory of fish population dynamics. Edinburgh: Oliver and Boyd. 352 p.

NUNES, DM., PELLANDA, M. and HARTZ, SM., 2004. Dinâmica reprodutiva de Oligosarcus jenynsii e Oligosarcus robustus (Characiformes, Characidae) na lagoa Fortaleza, Rio Grande do Sul Brasil. Iheringia. Série Zoologia, vol. 94, p. 5-11.

PEEL, MC., FINLAYSON, BL. and MCMAHON, TA., 2007. Updated world map of the Koppen-Geiger climate classification. Hydrology and Earth System Sciences, vol. 11, no. 5, p. 16331644. http://dx.doi.org/10.5194/hess-11-1633-2007.

PRUDENTE, BP., FERREIRA, MAP., ROCHA, RM. and MONTAG, LFA. 2015. Reproductive biology of the piranha Serrasalmus gouldingi (Fink and Machado-Allison 1992) (Characiformes: Serrasalmidae) in "drowned" rivers of the Eastern Amazon. Environment Biology of Fish, vol. 98, no. 1, p. 11-22.

QUEIROZ, HL., SOBANSKI, MB. and MAGURRAN, AE., 2010. Reproductive strategies of red-bellied piranha Pycocentrus nattereri (Kner, 1858) in the white waters of the Mamirauá flooded forest, central Brazilian Amazon. Environmental Biology of Fishes, vol. 89, no. 1, p. 11-19. http://dx.doi.org/10.1007/s10641-010-9658-1.

RODRIGUES-FILHO, JL., VERANI, JR., PERET, AC., SABINSON, LM. and BRANCO, JO., 2011. The influence of population structure and reproductive aspects of the genus Stellifer (Oken, 1817) on the abundance of species on the southern Brazilian coast. Brazilian Journal of Biology $=$ Revista Brasileira de Biologia, vol. 71, no. 4, p. 991-1002. http://dx.doi.org/10.1590/ S1519-69842011000500019. 
RUFFINO, ML. and ISAAC, VJ., 1995. Life cycle and biological parameters of several Brazilian Amazonfish species. NAGA ICLARM Quarterly, vol. 18, p. 41-45.

SABINSON, LM., RODRIGUES-FILHO, JL., PERET, AC. and VERANI, JR., 2014. Growth and reproduction aspects of Pimelodus maculatus Lacépède, 1803 (Siluriformes, Pimelodidae) of the Cachoeira Dourada reservoir, state of Goiás and Minas Gerais, Brazil. Brazilian Journal of Biology $=$ Revista Brasileira de Biologia, vol. 74, no. 2, p. 450-459. http://dx.doi.org/10.1590/15196984.09012. PMid:25166330.

SANTOS, GM., FERREIRA, E. and ZUANON, J., 2006. Peixes comerciais de Manaus. Manaus: IBAMA. 144 p.

SANTOS, HB., ARANTES, FP., SAMPAIO, EV. and SATO, Y., 2013. Artificial reproduction and reproductive parameters of the internally inseminated driftwood catfish Trachelyopterus galeatus (Siluriformes: Auchenipteridae). Ichthyological Research, vol. 60, no. 2, p. 142-148. http://dx.doi.org/10.1007/s10228-012-0324-9.
SILVA, AC. and VIANA, MSR., 2003. Época de desova do cangati, Trachycorystes galeatus (Linnaeus, 1756), no Açude Pereira de Miranda (Pentecoste-Ceará-Brasil). Revista Ciência Agronômica, vol. 34, p. 5-10.

SOUZA, JE., FRAGOSO-MOURA, EN., FENERICH-VERANI, N., ROCHA, O. and VERANI, JR., 2008. Population structure and reproductive biology of Cichla kelberi (Perciformes, Cichlidae) in Lobo Reservoir, Brazil. Neotropical Ichthyology, vol. 6, no. 2, p. 201-210. http://dx.doi.org/10.1590/S1679-62252008000200007.

VAZZOLER, AEAM., 1996. Biologia da reprodução de peixes teleósteos: teoria e prática. Maringá: EDUEM. 169 p.

ZAR, HJ., 2009. Biostatistical analysis. 5th ed. New Jersey: Pearson. 960 p.

ZEUG, SC. and WINEMILLER, KO., 2008. Relationships between hydrology, spatial heterogeneity, and fish recruitment dynamics in a temperate floodplain river. River Research and Applications, vol. 24, no. 1, p. 90-102. http://dx.doi.org/10.1002/rra.1061. 